\title{
Catherine S. Bradley, MD, MSCE
}

\section{Articles:}

Bradley CS, Rovner ES. Urodynamically defined stress urinary incontinence and bladder outlet obstruction coexist in women. J Urol. 2004 Feb;171(2 Pt 1):757-60; discussion 760-1.

Novi JM, Oloufa S, Brannigan J, Mulvihill BHK, Bradley CS. Timing of postoperative voiding trial after antiincontinence procedures. Journal of Pelvic Medicine and Surgery, 2004 Jan/Feb;10(1):37-8, 2004.

Nygaard I, Bradley C, Brandt D; Women's Health Initiative. Pelvic organ prolapse in older women: prevalence and risk factors. Obstet Gynecol. 2004 Sep;104(3):489-97.

Arya LA, Novi JM, Shaunik A, Bradley CS. Pelvic mass presenting as an irreducible vaginal vault prolapse. Journal of Pelvic Medicine \& Surgery, 2004 Sept/Oct;10(5):271-2.

Bradley CS, Rovner ES, Morgan MA, Berlin M, Novi JM, Shea JA, Arya LA. A new questionnaire for urinary incontinence diagnosis in women: development and testing. Am J Obstet Gynecol. 2005 Jan;192(1):66-73.

Bradley CS, Kennedy CM, Nygaard IE. Pelvic floor symptoms and lifestyle factors in older women. J Womens Health (Larchmt). 2005 Mar;14(2):12836.
Arya LA, Novi JM, Shaunik A, Morgan MA, Bradley CS. Pelvic organ prolapse, constipation, and dietary fiber intake in women: a case-control study. Am J Obstet Gynecol. 2005 May;192(5):168791.

Kennedy CM, Bradley CS, Galask RP, Nygaard IE. Risk factors for painful bladder syndrome in women seeking gynecologic care. Int Urogynecol J Pelvic Floor Dysfunct. 2006 Jan;17(1):73-8. Epub 2005 Jul 2.

Bradley CS, Nygaard IE. Vaginal wall descensus and pelvic floor symptoms in older women. Obstet Gynecol. 2005 Oct;106(4):759-66.

Subak LL, Brown JS, Kraus SR, Brubaker L, Lin F, Richter HE, Bradley CS, Grady D; Diagnostic Aspects of Incontinence Study Group. The "costs" of urinary incontinence for women. Obstet Gynecol. 2006 Apr;107(4):90816.

Brown JS, Bradley CS, Subak LL, Richter HE, Kraus SR, Brubaker L, Lin F, Vittinghoff E, Grady D; Diagnostic Aspects of Incontinence Study (DAISy) Research Group. The sensitivity and specificity of a simple test to distinguish between urge and stress urinary incontinence. Ann Intern Med. 2006 May 16;144(10):715-23. 
Sharp VJ, Bradley CS, Kreder KJ. Incontinence surgery in the older woman. Curr Opin Urol. 2006 Jul;16(4):224-8.

Bradley CS, Brown MB, Cundiff GW, Goode PS, Kenton KS, Nygaard IE, Whitehead WE, Wren PA, Weber AM; Pelvic Floor Disorders Network. Bowel symptoms in women planning surgery for pelvic organ prolapse. Am J Obstet Gynecol. 2006 Dec;195(6):1814-9. Epub 2006 Sep 25.

Richter HE, Fielding JR, Bradley CS, Handa VL, Fine P, FitzGerald MP, Visco A, Wald A, Hakim C, Wei JT, Weber AM; Pelvic Floor Disorders Network. Endoanal ultrasound findings and fecal incontinence symptoms in women with and without recognized anal sphincter tears. Obstet Gynecol. 2006 Dec;108(6):1394-401.

Wren PA., Janz NK, Brubaker L, Borello-France D, Bradley CS, Burgio K, Cundiff G, Weber A, Wei J. for the Pelvic Floor Disorders Network. Development of the Measure of Adaptations for Pelvic Symptoms (MAPS): the Importance of Incorporating the Female Patient's Voice. Applied Research in Quality of Life, 2006 Sep; 1(3-4):239-51, 2006.

Novi JM, Bradley CS, Mahmoud NN, Morgan MA, Arya LA. Sexual function in women after rectocele repair with acellular porcine dermis graft vs sitespecific rectovaginal fascia repair. Int Urogynecol J Pelvic Floor Dysfunct. 2007 Oct;18(10):1163-9. Epub 2007 Jan 11.

Scholarly Publications

Department of Obstetrics and Gynecology University of lowa, lowa City, IA
Richter HE, Burgio KL, Goode PS, Borello-France D, Bradley CS, Brubaker $L$, Handa VL, Fine PM, Visco AG, Zyczynski HM, Wei JT, Weber AM; Pelvic Foor Disorders Network. Nonsurgical management of stress urinary incontinence: ambulatory treatments for leakage associated with stress (ATLAS) trial. Clin Trials. 2007;4(1):92-101.

Bradley CS, Zimmerman MB, Qi Y, Nygaard IE. for the Women's Health Initiative. Natural history of pelvic organ prolapse in postmenopausal women. Obstet Gynecol. 2007 Apr;109(4):84854.

Brubaker L, Bradley CS, Handa VL, Richter HE, Visco A, Brown MB, Weber AM. Anal sphincter laceration at vaginal delivery: is this event coded accurately? Obstet Gynecol. 2007 May;109(5):11415.

Whitehead WE, Bradley CS, Brown MB, Brubaker L, Gutman RE, Varner RE, Visco AG, Weber AM, Zyczynski H; Pelvic Floor Network. Gastrointestinal complications following abdominal sacrocolpopexy for advanced pelvic organ prolapse. Am J Obstet Gynecol. 2007 Jul;197(1):78.e1-7.

Bradley CS, Richter HE, Gutman RE, Brown MB, Whitehead WE, Fine PM, Hakim C, Harford F, Weber AM; Pelvic Floor Disorders Network. Risk factors for sonographic internal anal sphincter gaps 6-12 months after delivery complicated by anal sphincter tear. Am J Obstet Gynecol. 2007 Sep;197(3):310.e1-5. 
Bradley CS, Nygaard IE, Brown MB, Gutman RE, Kenton KS, Whitehead WE, Goode PS, Wren PA, Ghetti C, Weber AM; Pelvic Floor Disorders Network. Bowel symptoms in women 1 year after sacrocolpopexy. Am J Obstet Gynecol. 2007 Dec;197(6):642.e1-8.

Bradley CS, Kennedy CM, Turcea AM, Rao SS, Nygaard IE. Constipation in pregnancy: prevalence, symptoms, and risk factors. Obstet Gynecol. 2007 Dec;110(6):1351-7.

Kennedy CM, Nygaard IE, Bradley CS, Galask RP. Bladder and bowel symptoms among women with vulvar disease: are they universal? J Reprod Med. 2007 Dec;52(12):1073-8.

Handa VL, Lockhart ME, Fielding JR, Bradley CS, Brubaker L, Cundiff GW, Ye W, Richter HE; Pelvic Floor Disorders Network. Racial differences in pelvic anatomy by magnetic resonance imaging. Obstet Gynecol. 2008 Apr;111(4):914-20.

Brubaker L, Handa VL, Bradley CS, Connolly A, Moalli P, Brown MB, Weber A; Pelvic Floor Disorders Network. Sexual function 6 months after first delivery. Obstet Gynecol. 2008 May;111(5):1040-4.

Bradley CS, Zimmerman MB, Wang Q, Nygaard IE; Women's Health Initiative. Vaginal descent and pelvic floor symptoms in postmenopausal women: a longitudinal study. Obstet Gynecol. 2008 May;111(5):1148-53.

\section{Scholarly Publications}

Department of Obstetrics and Gynecology University of lowa, lowa City, IA
Fitzgerald MP, Richter HE, Bradley CS, Ye W, Visco AC, Cundiff GW, Zyczynski HM, Fine P, Weber AM; Pelvic Floor Disorders Network. Pelvic support, pelvic symptoms, and patient satisfaction after colpocleisis. Int Urogynecol J Pelvic Floor Dysfunct. 2008 Dec;19(12):1603-9.

Bradley CS, Smith KE, Kreder KJ. Urodynamic evaluation of the bladder and pelvic floor. Gastroenterol Clin North Am. 2008 Sep;37(3):539-52, vii.

Bradley CS, Kenton KS, Richter HE, Gao X, Zyczynski HM, Weber AM, Nygaard IE; Pelvic Floor Disorders Network. Obesity and outcomes after sacrocolpopexy. Am J Obstet Gynecol. 2008 Dec;199(6):690.e1-8. Epub 2008 Oct 9.

Handa VL, Lockhart ME, Kenton KS, Bradley CS, Fielding JR, Cundiff GW, Salomon CG, Hakim C, Ye W, Richter $\mathrm{HE}$. Magnetic resonance assessment of pelvic anatomy and pelvic floor disorders after childbirth. Int Urogynecol J Pelvic Floor Dysfunct. 2009 Feb;20(2):133-9. Epub 2008 Oct 10.

Kennedy CM, Turcea AM, Bradley CS. Prevalence of vulvar and vaginal symptoms during pregnancy and the puerperium. Int $\mathrm{J}$ Gynaecol Obstet. 2009 Jun;105(3):236-9. Epub 2009 Mar 9.

Bradley CS, Rahn DD, Nygaard IE, Barber MD, Nager CW, Kenton KS, Siddiqui NY, Abel RB, Spino C, Richter $\mathrm{HE}$. The questionnaire for urinary incontinence diagnosis (QUID): Validity 
and responsiveness to change in women undergoing non-surgical therapies for treatment of stress predominant urinary incontinence. Neurourol Urodyn. 2009 Sep 28. [Epub ahead of print]

Gutman RE, Bradley CS, Ye W, Markland AD, Whitehead WE, Fitzgerald MP; for the Pelvic Floor Disorders Network. Effects of colpocleisis on bowel symptoms among women with severe pelvic organ prolapse. Int Urogynecol J Pelvic Floor Dysfunct. 2009 Dec 4. [Epub ahead of print]

\section{Book Chapters:}

Bradley C.S. Pessaries and devices: Non-surgical treatment of pelvic organ prolapse and stress urinary incontinence. In: Cardozo L., Staskin D.R., eds. Textbook of Female Urology and Urogynecology, 3rd edition. London: Informa, Healthcare. In press, 2009. 